
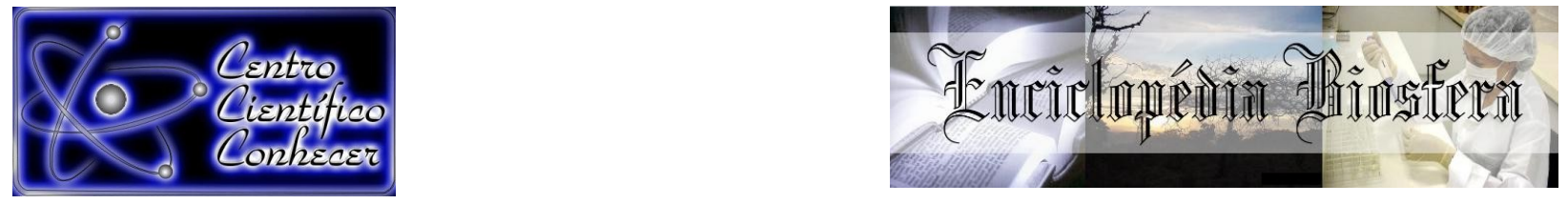

\title{
EVALUATION OF BIOMASS GASIFICATION VARIABLES CONSIDERING DIFFERENT DRAG MODEL APPROACHES
}

Marina Garcia Resende Braga ${ }^{1}$, Rodrigo Béttega², Gabriela Cantarelli Lopes ${ }^{3}$

1 Ph.D. candidate in Chemical Engineering at the Federal University of São Carlos (marinagr.eq@hotmail.com) São Carlos - Brazil

2 Professor in the Chemical Engineering Department of the Federal University of São Carlos - São Carlos - Brazil

3 Professor in the Chemical Engineering Department of the Federal University of São Carlos - São Carlos - Brazil

Recebido em: 06/04/2018 - Aprovado em: 10/06/2018 - Publicado em: 20/06/2018 DOI: 10.18677/EnciBio_2018A115

\begin{abstract}
Energy use and generation, and their effects on the environment, more than ever deserve attention nowadays. Studies and research must be constantly carried out in order to optimize different kinds of energy-related processes. In the chemical engineering context, biofuels emerge as a good alternative to fossil fuels, and one interesting process to obtain them is biomass gasification. The aim of this study was to evaluate how two different drag model approaches could influence some aspects of biomass gasification, such as solids volume fractions and radial particle velocities profiles, and also product mole fraction at the gasifier outlet, considering a circulating fluidized bed. The findings suggest that there was no significant difference in product mole fraction at the gasifier outlet when comparing the results obtained for both drag models. On the other hand, solids volume fraction along bed height, and radial particle velocity, showed some differences and presented a qualitative agreement with the literature.
\end{abstract}

KEYWORDS: CFD, biomass gasification, drag models.

\section{AVALIAÇÃO DE VARIÁVEIS DO PROCESSO DE GASEIFICAÇÃO DE BIOMASSA CONSIDERANDO DIFERENTES MODELOS DE ARRASTE}

\section{RESUMO}

O uso e geração de energia e seus efeitos sobre o meio ambiente, mais do que nunca, merecem atenção nos dias de hoje. Estudos e pesquisas devem ser realizados constantemente para otimização de todos os diferentes tipos de processos relacionados à energia. No contexto da Engenharia Química, os biocombustíveis surgem como uma boa alternativa para substituição dos combustíveis fósseis, e um processo interessante para obter esse tipo de combustível é a gaseificação de biomassa. O objetivo deste estudo foi avaliar como duas diferentes abordagens de modelos de arraste poderiam influenciar em alguns aspectos da gaseificação de biomassa, como em perfis de frações volumétricas de sólidos e velocidades radiais de sólidos, bem como também na fração molar de produtos na saída do gaseificador, considerando um leito fluidizado circulante. Os resultados sugerem que não houve diferença significativa na fração molar dos 
produtos na saída do gaseificador comparando-se os dois modelos de arraste testados. Por outro lado, os perfis de fração volumétrica de sólidos ao longo da altura do leito e as velocidades radiais de partículas mostraram algumas diferenças e apresentaram concordância qualitativa com os resultados da literatura.

PALAVRAS-CHAVE: CFD, gaseificação de biomassa, modelos de arraste.

\section{INTRODUCTION}

One of the main issues that society has to face nowadays is related to the use and generation of energy. Since the population has grown substantially over the years, the need for different types of energy sources has followed the same pattern (BARUAH; BARUAH, 2014). Therefore, constant research and studies in this area are increasingly important.

Recently, there has been a wide interest in biofuels, especially due to their renewable aspect. Several chemical processes can be used in order to obtain biofuels. One of those processes is gasification, which is a thermochemical process that converts carbon-derived products (biomass, oils, mineral coal, etc.) into gases that can generate energy (SANSANIWAL et al., 2017). Considerable advances have been achieved regarding modeling and simulation of hydrodynamic and kinetic aspects of biomass gasification processes over recent years, which can be seen in the works of Chaurasia (2016), Sharma and Sheth (2016), Ismail et al. (2016), Gagliano et al. (2017), Eri et al. (2018) and Wu et al. (2018).

Several reactor configurations can be used in biomass gasification processes, such as circulating fluidized beds (CFBs). In this type of configuration, the intense contact between the phases allows high heat and mass transfer (BARUAH; BARUAH, 2014). Computational Fluid Dynamics (CFD) tools have increasingly been applied to study the flow in gasifiers. In spite of not taking the gasification reactions into account, some studies have been important in understanding hydrodynamic behavior in circulating fluidized beds, such as velocity distributions and axial or radial solids and gas volume fractions (PÄRSSINEN; ZHU, 2001; ZHIXIN et al., 2016; BREAULT et al., 2017). In order to obtain adequate models to predict the behavior of solids in circulating fluidized beds, several types of modeling have been used over the years. Among others, the Eulerian-Eulerian approach has been shown suitable to simulate the gas-solid flow in CFBs. Using this approach, Wang et al. (2009) implemented a model for the drag force using the EMMS (Energy Minimization MultiScale) approach to simulate hydrodynamics in CFBs. A stochastic process was used to analyze the fluctuations in the behavior of volumetric fractions of solids along the riser, obtaining promising results.

Besides simulating the fluid flow in CFBs, some studies also took into account the gasification reactions in their CFD simulations. Patel et al. (2013), for example, carried out CFD simulations to analyze various parameters in a downstream airflow gasifier, such as turbulence influences, product gas composition, and temperature. The model developed by the authors was intended to predict the composition of the product gas, the temperature profile during the reactions, the unconverted char mass fraction, the initial pyrolysis zone temperature, the air inlet velocity and also pressure. The work is a good initial reference for comparison and analogy with results for biomass gasification, despite the use of coal, not biomass, as fuel. Liu et al. (2013) developed a pseudo-steady-state, 3-D, CFD simulation of the biomass gasification process in a circulating fluidized bed reactor. In their study, the standard turbulence $\kappa-\varepsilon$ model was coupled with the granular theory of kinetic flow. The kinetics of homogeneous and heterogeneous reactions were studied and integrated with 
continuity, momentum, energy and chemical species equations to describe the velocity, temperature, and concentration distributions. The authors obtained results similar to experimental data.

Nevertheless, the complexity of modeling and simulation of fluidized bed gasification is still an issue (VILLETTA et al., 2017). Regarding the study of different drag models, some research studies developed over the last decade can be highlighted, such as those developed by Hou et al. (2016) and Lv et al. (2016). Because of its complexity, many times, simplifications and hypotheses have to be applied to the gasification process simulation. The effects of the drag models on the performance of the gasification process in fluidized beds, for example, is a matter which still requires attention.

Therefore, the aim of this paper is to evaluate the influence of two different drag models on solid volume fraction and velocity profiles, as well as to investigate their importance to the gasification reactions, based on their main product yields, considering a circulating fluidized bed environment. A 2-D transient CFD model was used, considering the Eulerian-Eulerian approach, to simulate the gas-solid flow with reactions. A comparison between numerical results obtained in this study and experimental data from literature was drawn.

\section{MATERIAL AND METHODS}

\section{Mathematical Modeling}

In this paper, a multiphase reactive flow (gas-solid) was studied. The gas phase was represented by air and the solid phase by olive oil waste particles, as in the work by García-lbañez et al. (2004). The model developed was two-dimensional and transient, based on the Eulerian-Eulerian approach. Conservation equations for the phases are given below, with subscripts " $s$ " and "g" representing solid and gas phases, respectively.

Mass conservation equations for gas and solid phases are represented by Equations 1 and 2, respectively:

$$
\begin{aligned}
& \frac{\partial \varepsilon_{g} \rho_{g}}{\partial t}+\nabla .\left(\varepsilon_{g} \rho_{g} \mathbf{v}_{g}\right)=S_{g s} \\
& \frac{\partial \varepsilon_{s} \rho_{s}}{\partial t}+\nabla .\left(\varepsilon_{s} \rho_{s} \mathbf{v}_{s}\right)=S_{s g}
\end{aligned}
$$

in which the term on the right of the equation $(S)$ represents the mass exchange (generation or consumption) between the solid and gas phases due to the heterogeneous chemical reactions considered. Also, $\mathrm{t}, \varepsilon, \rho$ and $\mathbf{v}$ stand for time (s), volume fraction (-), density $\left(\mathrm{kg} \cdot \mathrm{m}^{-3}\right)$ and velocity vector $\left(\mathrm{m}^{-1}\right)$, respectively.

Momentum conservation for gas and solid phases is given by Equations 3 and 4, respectively:

$$
\begin{aligned}
& \frac{\partial \varepsilon_{g} \rho_{g} \mathbf{v}_{g}}{\partial t}+\nabla .\left(\varepsilon_{g} \rho_{g} \mathbf{v}_{g} \mathbf{v}_{g}\right)=-\varepsilon_{g} \nabla p+\nabla .\left(\bar{\tau}_{g}+\bar{\tau}_{g}^{\prime}\right)+\varepsilon_{g} \rho_{g} \mathbf{g}+S_{g s} \mathbf{v}_{s}+\beta\left(\mathbf{v}_{s}-\mathbf{v}_{g}\right) \\
& \frac{\partial \varepsilon_{s} \rho_{s} \mathbf{v}_{s}}{\partial t}+\nabla .\left(\varepsilon_{s} \rho_{s} \mathbf{v}_{s} \mathbf{v}_{s}\right)=-\varepsilon_{s} \nabla p+\nabla p_{s}+\nabla .\left(\bar{\tau}_{s}+\bar{\tau}_{s}^{\prime}\right)+\varepsilon_{s} \rho_{s} \mathbf{g}+S_{s g} \mathbf{v}_{s}+\beta\left(\mathbf{v}_{g}-\mathbf{v}_{s}\right)
\end{aligned}
$$

where $\bar{\tau}\left(\mathrm{N} \cdot \mathrm{m}^{-2}\right)$ and $\bar{\tau}^{-}\left(\mathrm{N} \cdot \mathrm{m}^{-2}\right)$ stand for laminar and Reynolds stress tensors respectively, $p$ is the pressure field $\left(\mathrm{kg}^{-1} \cdot \mathrm{m}^{-2}\right)$, $\mathbf{g}$ is the gravity vector $\left(\mathrm{m} \cdot \mathrm{s}^{-2}\right)$ and $\beta$ represents the momentum transfer coefficient between gas and solid phases. In 
order to calculate granular temperature for solids pressure and viscosities, the Kinetic Theory of Granular Flow (KTGF) was applied (LIU et al., 2013).

Energy conservation for both phases (gas and solid, respectively) is represented by Equations 5 and 6:

$$
\begin{aligned}
& \frac{\partial \varepsilon_{g} \rho_{g} H_{e g, g}}{\partial t}+\nabla \cdot\left(\varepsilon_{g} \rho_{g} \mathbf{v}_{g} H_{e g, g}\right)=\nabla . \lambda_{e f, g} \nabla T_{g}+S_{g s}+Q_{g s} \\
& \frac{\partial \varepsilon_{s} \rho_{s} H_{e g, s}}{\partial t}+\nabla .\left(\varepsilon_{s} \rho_{s} \mathbf{v}_{s} H_{e g, s}\right)=\nabla . \lambda_{e f, s} \nabla T_{s}+S_{s g}+Q_{s g}
\end{aligned}
$$

where $H_{e g}, \lambda_{\text {ef }}, T$ and $Q$ represent specific enthalpy for each phase $\left(\mathrm{J}^{\mathrm{kg}} \mathrm{kg}^{-1}\right)$, effective thermal conductivity $\left(\mathrm{W} \cdot \mathrm{m}^{-1} \cdot \mathrm{K}^{-1}\right)$, temperature $(\mathrm{K})$ and quantity of heat exchange between phases $\left(\mathrm{J} \cdot \mathrm{s}^{-1}\right)$, respectively. Heat transferred by radiation was not considered.

The species transport was modeled according to Equation 7:

$$
\frac{\partial\left(\rho_{g, s} \varepsilon_{g, s} Y_{i_{g, s}}\right)}{\partial t}+\nabla \cdot\left(\rho_{g, s} \varepsilon_{g, s} \mathbf{v}_{g, s} Y_{g_{g, s}}\right)=-\nabla . \varepsilon_{g, s} J_{i_{g, s}}+\varepsilon_{g, s} R_{e i_{g, s}}+R_{e}
$$

where $J_{i}\left(\mathrm{~kg} \cdot \mathrm{m}^{2} \cdot \mathrm{s}^{-1}\right)$ is the diffusion flux of the species, which is given by Equation 8:

$$
J_{i_{g, s}}=-\left(\rho_{g, s} D_{t i_{g, s}} \frac{\mu^{t}}{S c_{t}}\right) \frac{\dot{\dagger}}{i} \nabla Y_{i_{g, s}}-D_{t T, i} \frac{\nabla T}{T}
$$

in which $Y_{i}(-)$ represents the mass fraction of each species "i" in the system. The net rate of reaction or consumption due to homogeneous reactions of each species $i$ is given by $R_{e i}\left(\mathrm{~kg}^{-3} \mathrm{~m}^{-1}\right)$ while $R_{e}\left(\mathrm{~kg}^{-3} \mathrm{~m}^{-3} \mathrm{~s}^{-1}\right)$, represents the same, but referring to heterogeneous reactions. The mass diffusion coefficient of each species is given by $D_{t i}\left(\mathrm{~m}^{2} \cdot \mathrm{s}^{-1}\right)$, and $D_{t T, i}\left(\mathrm{~m}^{2} \cdot \mathrm{s}^{-1}\right)$ represents their thermal diffusion coefficient. The turbulent Schmidt number is also taken into account in the diffusion calculation of the species, being represented by $S c_{t}(-)$. Finally, $\mu^{t}$ (Pas) stands for turbulent viscosity.

For the sake of solving Equations 3 to 7 , some additional terms have to be used. The main terms required by this model include stress tensors, responsible for modeling the distribution of stresses and other internal stresses in continuous media. Those tensors are modeled as follows:

$$
\begin{aligned}
& \overline{\tau_{g, s}}=\varepsilon_{g, s} \mu_{g, s}\left(\nabla \mathbf{v}_{g, s}+\nabla \mathbf{v}_{g, s}{ }^{T}\right)+\varepsilon_{g, s}\left(\xi_{g, s}-\frac{2}{3} \mu_{g, s}\right) \bar{\delta} \\
& \overline{\tau_{g, s}}=\varepsilon_{g, s} \mu_{g, s}^{t}\left(\nabla \mathbf{v}_{g, s}+\nabla \mathbf{v}_{g, s}{ }^{T}\right)-\frac{2}{3}\left(\varepsilon_{g, s} \rho_{g, s} K_{g, s}+\varepsilon_{g, s} \mu_{g, s}^{t} \nabla . \mathbf{v}_{g, s}\right) \bar{\delta}
\end{aligned}
$$

where the shear viscosity is given by $\mu$ (Pas), $\xi$ (Pas) is the bulk viscosity and $\delta(-)$ is a unit tensor.

The main focus of this paper is related to interphase momentum transfer, considered to be only due to drag force, represented by $\beta$. The drag models, which can be used, are divided into two main categories: conventional drag models and EMMS (Energy Minimization Multiscale) drag models (WU et al., 2018). The models used in this work are described below. 
This category includes drag models such as the ones developed by Gidaspow et al. (2004). Usually, this type of model is derived from data of particle terminal velocity and pressure drop (LIU et al., 2013). The Gidaspow model was chosen to be tested in this study, for its reliability and for being a well-known and constantly used model in the literature. The calculation of drag coefficient in the Gidaspow drag model depends on a porosity condition, as shown below by Equation 11 (Ergun model) and Equation 12 (Wen and Yu model), while Equations 13 and 14 representing drag coefficient $C_{d}(-)$ and how the particle Reynolds number $\left(R e_{p}\right)$ was calculated, respectively:

For $\varepsilon_{g} \leq 0.8$ :

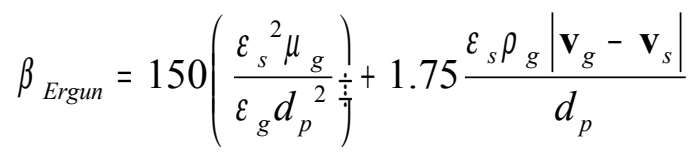

For $\varepsilon_{g}>0.8$ :

$$
\begin{aligned}
& \beta_{\text {Wen\&Yu }}=\frac{3}{4} C_{d} \frac{\varepsilon_{s} \varepsilon_{g} \rho_{g}\left|\mathbf{v}_{g}-\mathbf{v}_{s}\right| \varepsilon_{g}{ }^{-2.65}}{d_{p}} \\
& C_{d}=\frac{24}{\varepsilon_{g} \operatorname{Re}_{p}}\left[1+0.15\left(\varepsilon_{g} \operatorname{Re}_{p}\right)^{0.687}\right] \\
& \operatorname{Re}_{p}=\frac{\rho_{g}\left|\mathbf{v}_{g}-\mathbf{v}_{s}\right| d_{p}}{\mu_{g}}
\end{aligned}
$$

where $^{d_{p}}(\mathrm{~m})$ represents the particle diameter.

\section{Energy Minimization Multiscale Models (EMMS)}

The flow conditions in a CFB biomass gasification reactor sometimes lead to formation of clusters, which coexist and interact with the dilute fluid phase. The conventional drag models are not capable of representing accurately this aspect. Hence it is necessary to use a model that accounts for the effect of flow heterogeneity on the drag force.

Yang et al. (2004) derived a drag correlation based on some simplifications of the overall EMMS approach, adding a new variable as well: the average acceleration of particles for a control volume. The drag model is shown by Equations 11 and 15:

For $\varepsilon_{g}<0.74$ : Equation 11

For $\varepsilon_{g} \geq 0.74$ :

$$
\beta_{\text {Wen\&Yu }}=\frac{3}{4} C_{d} \frac{\varepsilon_{s} \varepsilon_{g} \rho_{g}\left|\mathbf{v}_{g}-\mathbf{v}_{s}\right|}{d_{p}} \omega
$$

The correction factor $\omega(-)$ depends on each flow-specific characteristic, especially the local voidage. Shah et al. (2011) derived a set of equations for correction factors for both low- and high-mass solid fluxes. In this work, the mass solid flux is low; therefore, Equations 16 to 18 were used:

For $\varepsilon_{g} \leq 0.78$ : Equation 11

For $\varepsilon_{g}>0.78$ : 


$$
\begin{aligned}
& \omega\left(\varepsilon_{g}\right)=-3.867 \times 10^{-2}+\frac{6.893 \times 10^{-3}}{4\left(\varepsilon_{g}-0.761\right)^{2}+1.599 \times 10^{-3}}\left(0.78<{ }^{\varepsilon_{g}} \leq 0.86\right) \\
& \omega\left(\varepsilon_{g}\right)=-1.283 \times 10^{-2}+\frac{3.940 \times 10^{-3}}{4\left(\varepsilon_{g}-0.782\right)^{2}+2.711 \times 10^{-3}}\left(0.86<{ }^{\varepsilon_{g}} \leq 0.97\right) \\
& \omega\left(\varepsilon_{g}\right)=-31.859+32.859 \varepsilon_{g} \quad\left({ }^{\varepsilon_{g}}>0.97\right)
\end{aligned}
$$

\section{Pyrolysis}

Pyrolysis is a process of raw material thermal degradation, in the absence of air or oxygen, originating solid products (char and ash), liquids (tar and other organic species in small quantity) and gases $\left(\mathrm{CO}_{2}, \mathrm{CO}, \mathrm{H}_{2}, \mathrm{H}_{2} \mathrm{O}, \mathrm{CH}_{4}\right.$, and $\mathrm{C}_{2} \mathrm{H}_{4}$, among others). The mathematical and computational modeling of the pyrolysis process has been widely studied by several authors (BARUAH; BARUAH, 2014), but all models developed have certain limitations. The biomass molecular formula was obtained by its ultimate analysis, as shown in Table 1. Only carbon, hydrogen and oxygen were taken into account. Proximate analysis of biomass was also important to close the pyrolysis model. The pyrolysis may or not be instantaneous, depending on the temperature of the reactor. In this work, the pyrolysis process was considered instantaneous.

\begin{tabular}{|c|c|c|c|c|c|c|c|c|}
\hline \multicolumn{6}{|c|}{ Ultimate analysis (wt \%, dry ash basis) } & \multicolumn{3}{|c|}{$\begin{array}{c}\text { Proximate analysis (wt \%, } \\
\text { dry ash) }\end{array}$} \\
\hline C & $\mathbf{H}$ & $\mathbf{N}$ & $\mathbf{S}$ & Cl & $\mathbf{0}$ & $\begin{array}{l}\text { Volatile } \\
\text { matter }\end{array}$ & $\begin{array}{l}\text { Fixed } \\
\text { carbon }\end{array}$ & Ash \\
\hline 52.7 & 7.2 & 1.6 & 0.07 & 0.37 & 38.1 & 74.4 & 1.71 & 8.5 \\
\hline
\end{tabular}

TABLE 1 - Ultimate and proximate analysis of olive oil waste for biomass gasification (GARCÍA-IBAÑEZ et al., 2004).

For this work, a one-step model was used to obtain all the products generated in the biomass pyrolysis. As a simplification, tar formation was not considered, since it would increase the complexity of the model in a very significant way. Thus, the chemical reaction responsible for pyrolysis modeling was defined according to Equation 19.

$$
\text { Biomass } \rightarrow \alpha_{\text {char }} \mathrm{CHAR}+\alpha_{1} \mathrm{CO}+\alpha_{2} \mathrm{CO}_{2}+\alpha_{3} \mathrm{CH}_{4}+\alpha_{4} \mathrm{C}_{2} \mathrm{H}_{4}+\alpha_{5} \mathrm{H}_{2} \mathrm{O}+\alpha_{6} \mathrm{H}_{2}
$$

It was assumed that biomass entered into the gasifier on a dry basis. Another assumption was that char and ash were formed only by carbon (BOATENG; MTUI, 2012). In order to determine the stoichiometric coefficients of the volatiles reaction, atomic molar balances of each element were made, following the same model developed by Boateng and Mtui (2012), in which the following results were obtained: $\alpha_{1}=0.2597, \alpha_{2}=0.1037, \alpha_{3}=0.1594, \alpha_{4}=0.1106, \alpha_{5}=0,0749$ and $\alpha_{6}=0,2046$.

A User Defined Function (UDF) was used to implement pyrolysis reaction rate in ANSYS Fluent. The Arrhenius equation was used, according to the model proposed by Liu et al. (2013).

\section{Heterogeneous reactions}


In order to model heterogeneous reactions properly, both kinetic and mass diffusivity effects are considered in the reaction rates formulations, represented by $r_{h}$ $\left(\mathrm{kg} \mathrm{m}^{-3} \mathrm{~s}^{-1}\right)$ (WANG et al., 2009; GERBER et al., 2010; LIU et al., 2013). Char reactions with gases inside the reactor are represented by Equations 20 to 23 .

$$
\begin{aligned}
& \mathrm{C}+\mathrm{O}_{2} \rightarrow \mathrm{CO}_{2} \\
& \mathrm{C}+\mathrm{CO}_{2} \rightarrow 2 \mathrm{CO} \\
& \mathrm{C}+\mathrm{H}_{2} \mathrm{O} \rightarrow \mathrm{CO}+\mathrm{H}_{2} \\
& \mathrm{C}+2 \mathrm{H}_{2} \rightarrow \mathrm{CH}_{4}
\end{aligned}
$$

A global scheme taking both the kinetic and the mass diffusivity into account was applied according to Equations 24 to 29. The same scheme was similarly applied by Wang et al. (2009), Gerber et al. (2010) and Liu et al. (2013):

$$
\begin{aligned}
& r_{h}=\frac{6 V_{c} k_{h}}{d_{p}} p_{i} \\
& k_{h}=\frac{1}{\left(\left(\frac{1}{k_{c}} \frac{\dot{ }}{j}+\left(\frac{1}{k_{d}}\right)\right)\right.} \\
& \left.k_{c}=A T_{p}^{n} \exp \left(\frac{E_{a}}{R_{\text {gases }} T_{p}}\right) \frac{\dot{1}}{\dot{j}}\right) \\
& k_{d}=\frac{S h D_{g s} M_{c}}{R_{\text {gases }} T_{p} d_{p}} \\
& S h=2+0.6 \operatorname{Re}^{1 / 2} S c^{1 / 3} \\
& D_{g s}=\frac{8.34 \times 10^{-6}}{p}
\end{aligned}
$$

where $D_{g s}\left(\mathrm{~m}^{2} \mathrm{~s}^{-1}\right)$, Sh $(-), V_{c}\left(\mathrm{~m}^{3}\right), M_{c}\left(\mathrm{~kg} \mathrm{kmol}^{-1}\right)$ and $R_{\text {gases }}\left(\mathrm{J} \cdot \mathrm{mol}^{-1} \mathrm{~K}^{-1}\right)$ stand for pressure, mass diffusivity coefficient, Sherwood number, volume and molecular weight of char and gas universal constant, respectively. A and $E_{a}$ are the preexponential factor and activation energy for the Arrhenius equation. Finally, $k_{d}, k_{c}$ and $k_{h}$ represent kinetic parameters related to mass diffusion and kinetics and both of them together, respectively. UDFs were also necessary to model all the equations in this case.

\section{Homogeneous reactions}

Homogeneous reactions applied in this study are shown in Equations 30 to 33. The kinetic parameters related to these reactions are the same used by Liu et al. (2013), and all of them were simulated according to the Arrhenius kinetics.

$$
\begin{aligned}
& \mathrm{CO}+0.5 \mathrm{O}_{2} \rightarrow \mathrm{CO}_{2} \\
& \mathrm{H}_{2}+0.5 \mathrm{O}_{2} \rightarrow \mathrm{H}_{2} \mathrm{O} \\
& \mathrm{CH}_{4}+2 \mathrm{O}_{2} \rightarrow \mathrm{CO}_{2}+2 \mathrm{H}_{2} \mathrm{O} \\
& \mathrm{C}_{2} \mathrm{H}_{4}+\mathrm{O}_{2} \rightarrow 2 \mathrm{CO}+2 \mathrm{H}_{2}
\end{aligned}
$$

\section{Numerical Modeling}




\section{Computational Domain and Numerical Mesh}

A 6.5-m-high gasifier with a diameter of $0.20 \mathrm{~m}$ makes up the computational domain, which was developed using ANSYS ICEM-CDF. The geometry created was axisymmetric, with an inclusion of a lateral entrance for biomass, while air enters at the bottom and both air and biomass products leave the gasifier at the top.

In order to obtain a more robust numerical solution, a grid independence test was carried out. The mesh used in the simulations had 162,500 elements, and it was also created with the same software as the geometry.

\section{Boundary Conditions and Simulation Settings}

All boundary and operational conditions used in the simulation are summarized in Table 2 (GARCÍA-IBAÑEZ et al., 2004; LIU et al., 2013). Five user-defined functions (UDFs) were necessary to model the heterogeneous reactions, including pyrolysis.

TABLE 2 - Boundary and operational conditions for the simulation of biomass gasification process.

\begin{tabular}{ll}
\hline \multicolumn{1}{c}{ Variables } & \multicolumn{1}{c}{ Values } \\
\hline Inlet gas volumetric flow rate & $\begin{array}{l}109 \mathrm{Nm}^{3} \mathrm{~h}^{-1} \text { (converted to velocity } \\
\text { inlet) }\end{array}$ \\
Biomass feed rate & $60 \mathrm{kgh}^{-1}$ (Mass flow inlet) \\
Equivalence ratio & 0.41 \\
Pressure & $1.0 \mathrm{~atm}$ \\
Wall conditions (gas and solid & No slip \\
phases) & 0.20 \\
Gasifier diameter & 6.5 \\
Gasifier height & $\mathrm{k}-\mathrm{epsilon}$ \\
Turbulence model & Standard Wall Functions \\
Wall treatment & Gidaspow and EMMS \\
Drag models & None \\
Radiation models & $873.15 \mathrm{~K}$ \\
Inlet biomass temperature & $1273.15 \mathrm{~K}$ \\
Inlet air temperature & \\
\hline
\end{tabular}

Physical properties of air and biomass used in this simulation are presented in Table 3. It is important to note that ultimate and proximate analysis values have already been presented in Table 1.

TABLE 3 - Main physical properties and characteristics of both phases used in the present model (GARCÍA-IBAÑEZ et al., 2004; LIU et al., 2013).

\begin{tabular}{l|l}
\hline \multicolumn{1}{c|}{ Property } & \multicolumn{1}{c}{ Value } \\
\hline Gas density & $1.225 \mathrm{~kg}^{-3}$ \\
Gas viscosity & $1.72 \times 10^{-5} \mathrm{~kg} \mathrm{~m}^{-3}$ \\
Solid density & $659 \mathrm{~kg} \mathrm{~m}^{-3}$ \\
\hline
\end{tabular}


In order to solve the partial nonlinear differential equations presented in the mathematical modeling of the biomass gasification process, the finite volume method was used. This method is available in ANSYS Fluent version 14.5, chosen for the preprocessing, solving and post-processing CFD steps of the results. Case geometry and mesh were generated in ANSYS ICEM-CFD version 14.5.

The method SIMPLE (Semi-implicit Method for Pressure-Linked Equations) was used for pressure-velocity coupling. The first-order upwind was used to analyze convective flows through volume faces, while the first-order Euler implicit scheme was chosen to solve temporal discretization. Variables gradient for diffusion term discretization in the conservation equations was solved by the Least-Square CellBased method.

The simulation was performed considering a criterion of residues convergence below $10^{-3}$ and a maximum of 25 iterations per time step. In order to obtain a more developed hydrodynamics profile in the reactor, $15 \mathrm{~s}$ were simulated initially, without considering the occurrence of chemical reactions. After that time had passed, another $45 \mathrm{~s}$ of reactions were simulated.

\section{RESULTS AND DISCUSSION}

The radial particle velocities profiles obtained for the different drag approaches are shown in Figure 1. These profiles are significantly affected by the drag model used.

a)

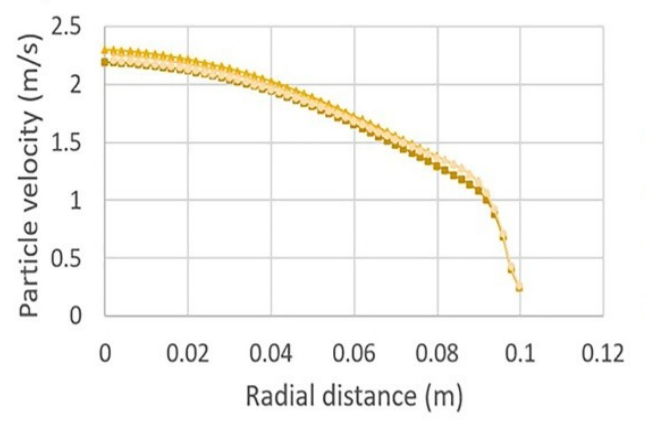

b)

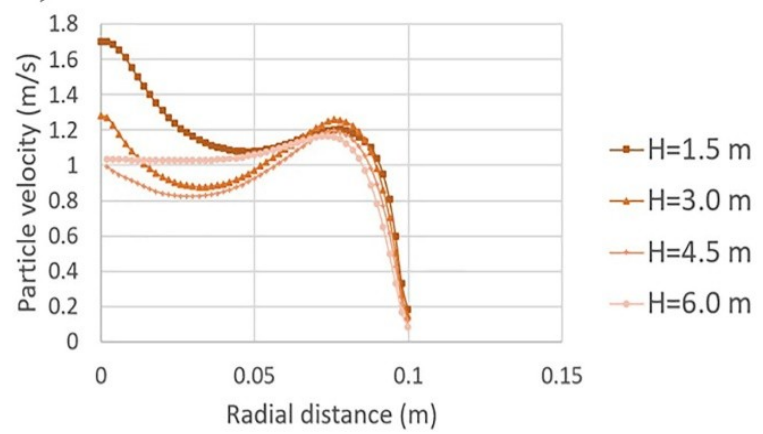

FIGURE 1 - Particle velocity profiles along gasifier height considering four different heights for: a) Gidaspow model and b) EMMS model.

Although there is no experimental data from García-lbañez et al. (2004) available for comparison regarding the radial distribution of particle velocity, the results can be compared to other studies in the literature. The hydrodynamic behavior concerning circulating fluidized beds has been extensively studied. Cruz et al. (2006) proposed a CFD model in which solids accumulation was observed in wall regions, redirecting the gas to the central region of the equipment, a behavior also observed during the present study. A similar profile for radial particle velocity using an EMMS drag model approach was also obtained by Wang and Liu (2010). From the present study, it can be inferred that the heterogeneity caused by the EMMS model led to qualitative differences between radial particle velocity profiles between the two models tested. This heterogeneity, and also the impact of particle velocities in solid volume fraction contours along bed height considering both drag models, can be observed in Figure 2. 


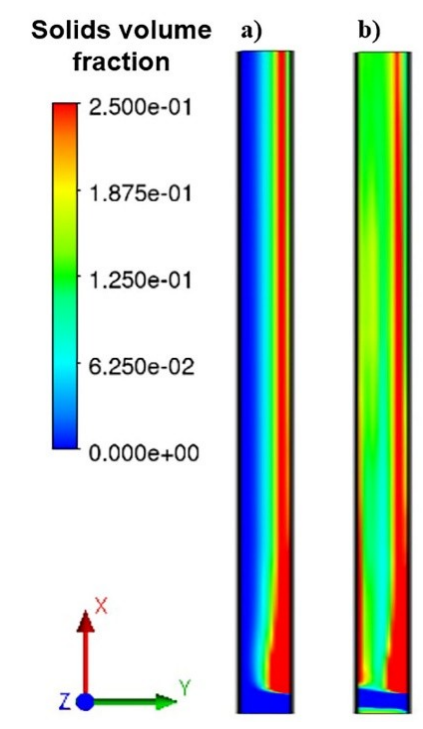

FIGURE 2 - Solid volume fraction contours for: a) Gidaspow drag model and b) EMMS drag model.

The solids volume fraction profile along gasifier height is shown in Figure 3. It was obtained by averaging the solids volume fraction in cross sections located at different heights.

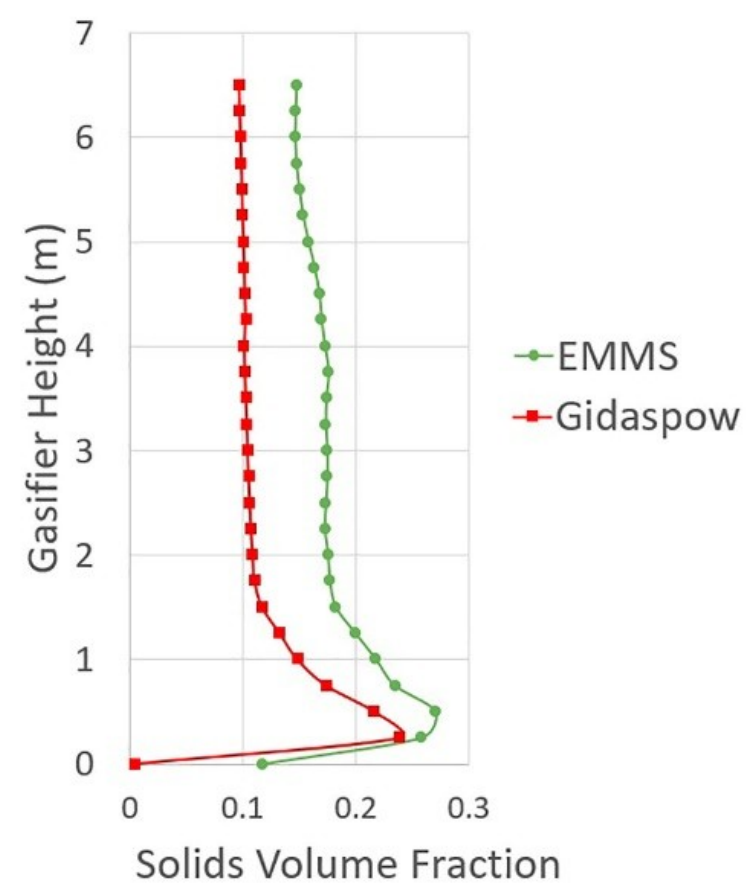

FIGURE 3 - Solids volume fraction along gasifier height using two different drag models.

The results obtained in Figure 3 corroborate preview studies in the literature, such as in Pärssinen and Zhu (2001) and Shah et al. (2011). It can be seen that the Gidaspow drag model can predict better more dilute regions in the gasifier, while the use of drag models with an EMMS approach are able to predict denser regions better. 
Mole fraction profiles along gasifier height of some gasification products obtained for both drag models can be seen in Figure 4. Also, Table 4 shows some molar fractions of the main biomass gasification products obtained in this study compared to experimental data of García-lbañez et al. (2004).

a)

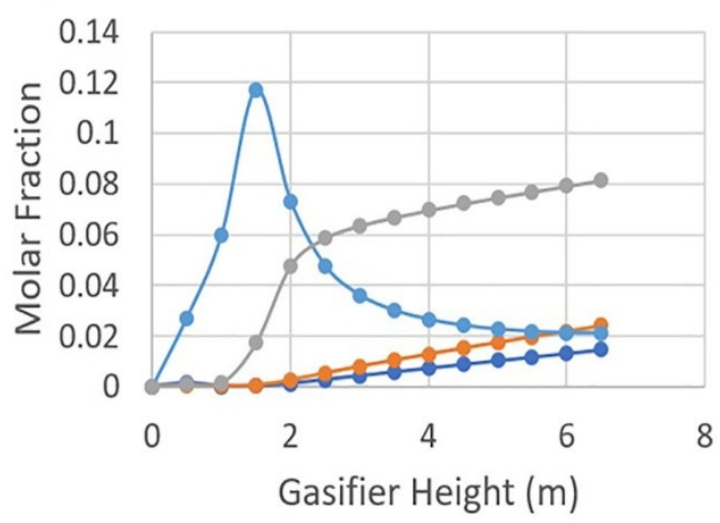

b)

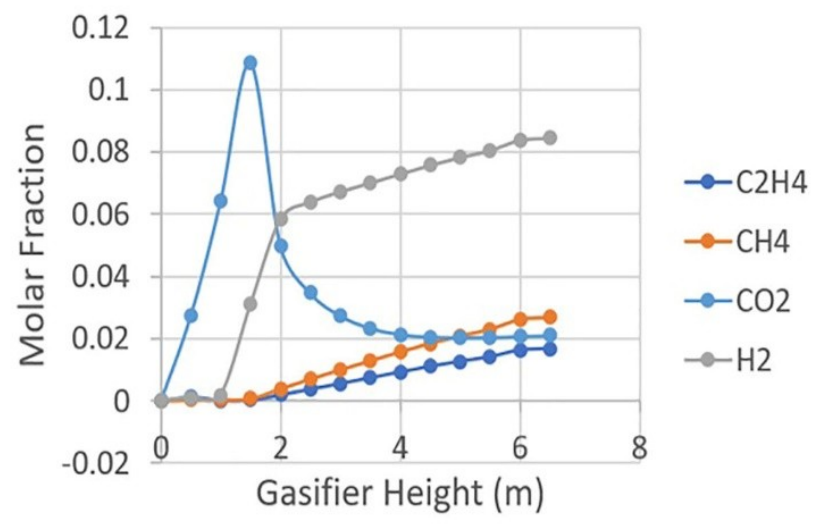

FIGURE 4 - The molar fraction of some biomass gasification products along gasifier height considering: a) Gidaspow model and b) EMMS model.

TABLE 4 - Molar fractions of the main biomass gasification products obtained in the present study compared with experimental data from GarcíaIbañez et al. (2004).

\begin{tabular}{ccccccc}
\hline Species & $\mathrm{C}_{2} \mathrm{H}_{4}$ & $\mathrm{CH}_{4}$ & $\mathrm{CO}$ & $\mathrm{CO}_{2}$ & $\mathrm{H}_{2}$ & $\mathbf{N}_{2}$ \\
\hline $\begin{array}{c}\text { García-lbañez } \\
\text { et al. (2004) }\end{array}$ & 0.016 & 0.03 & 0.086 & 0.217 & 0.054 & 0.595 \\
$\begin{array}{c}\text { EMMS model } \\
\text { Gidaspow } \\
\text { model }\end{array}$ & 0.017 & 0.027 & 0.336 & 0.021 & 0.085 & 0.520 \\
\hline
\end{tabular}

It can be observed from Figure 4 and Table 4 that the molar fractions of $\mathrm{C}_{2} \mathrm{H}_{4}$, $\mathrm{CH}_{4}, \mathrm{H}_{2}$, and $\mathrm{N}_{2}$ are in significant agreement with the literature (GARCÍA-IBAÑEZ et al., 2004). However, the $\mathrm{CO}$ and $\mathrm{CO}_{2}$ fractions presented divergences compared with experimental data. One possible explanation for this is the fact that the water-gas reaction is not considered in this model. This reaction is represented by Equation 34 .

$\mathrm{CO}+\mathrm{H}_{2} \mathrm{O} \leftrightarrow \mathrm{H}_{2}+\mathrm{CO}_{2}$

From Equation 34, one can notice that the reaction products are $\mathrm{CO}_{2}$ and $\mathrm{H}_{2}$, while the reactants are $\mathrm{CO}$ and $\mathrm{H}_{2} \mathrm{O}$. The molar fraction of $\mathrm{CO}_{2}$ and $\mathrm{CO}$ obtained in this work showed a significant divergence from experimental data, which can be explained by the aforementioned absence of the reaction, since they are one of the reaction products and reactants, respectively. Despite this, the value of the $\mathrm{H}_{2}$ mole fraction was not significantly affected.

There are some factors that may explain the divergence between the results obtained in the model and in the literature. For example, the comparison between a 2-D simulation with experimental data obtained in 3-D reactors can always lead to errors. Also, the modeling used in this work was based on Liu et al. (2013), but with 
some remarkable differences. The model presented in the aforementioned work was developed in a 3-D environment and simulated in a pseudo-stationary state. In such study, the environment considered was 2-D and the regime was transient. Finally, the pyrolysis model has proved to be the most challenging of all, it was the case with the least amount of data available in the literature.

As shown in Table 4 and Figure 4, mole fractions of the products generated by the biomass gasification process did not change significantly with the use of two different drag models. It shows that the process hydrodynamics do not significantly alter the final result of reactants conversion. This can be explained by the fact that the heterogeneous reactions, which depend on the concentration of solids in the system, are probably faster than the homogeneous, especially in high-temperature environments such as gasification.

\section{CONCLUSION}

The results presented in this work indicate that the use of two different drag approaches did not have a significant influence on the molar fraction of the process products at the outlet of the gasifier. This can be explained by the high speed of the heterogeneous reactions of the process; mainly the pyrolysis and the reactions of the char with oxygen and with the gases formed by the pyrolysis itself. High temperatures may favor the conversion of the reactants into products in these types of reactions. A great influence on the fluid dynamics of the gasifier of the reagent gases and the products of homogeneous reactions was observed.

Taking into consideration the axial solid volume fraction of some biomass products, EMMS drag models are able to predict better the denser regions in the gasifier, while the Gidaspow model, similarly to other conventional drag models, can predict dilute regions more accurately. Moreover, radial particle velocity profiles were presented and showed qualitative agreement with the literature.

Although the drag model did not have great influence on the mole fraction of biomass gasification products, more investigation is still required, since the model simplifications considered here may have influenced the results.

\section{ACKNOWLEDGMENTS}

The authors would like to thank the Graduate Program at Federal University of São Carlos (PPG-EQ/UFSCar) and CNPq.

\section{REFERENCES}

BARUAH, D.; BARUAH, D. C. Modeling of biomass gasification: A review. Renewable and Sustainable Energy Reviews, v. 39, p. 806-815, 2014. Disponível em: <http://dx.doi.org/10.1016/j.rser.2014.07.129>. doi: 10.1016/j.rser.2014.07.129.

BOATENG, A. A.; MTUI, P. L. CFD modeling of space-time evolution of fast pyrolysis products in a bench-scale fluidized-bed reactor. Applied Thermal Engineering, v. 33-34, p. 190-198, 2012. Disponível em: <http://dx.doi.org/10.1016/j.applthermaleng.2011.09.034>. doi: 10.1016/j.applthermaleng.2011.09.034.

BREAULT, R. W.; MONAZAM, E. R.; SHADLE, L. J.; ROWAN, S.; MACFARLAN, L. $H$. The effect of riser end geometry on gas-solid hydrodynamics in a CFB riser operating in the core annular and dilute homogeneous flow regimes. Powder 
Technology, v. 316, p. 181-189, 2017. Disponível em: <https://doi.org/10.1016/j.powtec.2017.02.017>. doi: 10.1016/j.powtec.2017.02.017.

CHAURASIA, A. Modeling, simulation and optimization of downdraft gasifier: Studies on chemical kinetics and operating conditions on the performance of the biomass gasification process. Energy, v. 116, p. 1065-1076, 2016. Disponível em: <http://dx.doi.org/10.1016/j.energy.2016.10.037>. doi: 10.1016/j.energy.2016.10.037.

CRUZ, E.; STEWARD, F. R.; PUGSLEY, T. New closure models for CFD modeling of high-density circulating fluidized beds. Powder Technology, v.169, p. 115-122, 2006. Disponível em: <https://doi.org/10.1016/j.powtec.2006.08.005>. doi: 10.1016/j.powtec.2006.08.005.

ERI, Q.; PENG, J.; ZHAO, X. CFD simulation of biomass steam gasification in a fluidized bed based on a multi-composition multi-step kinetic model. Applied Thermal Engineering, v. 129, p. 1358-1368, 2018. Disponível em: <https://doi.org/10.1016/j.applthermaleng.2017.10.122>. doi: 10.1016/j.applthermaleng.2017.10.122.

GAGLIANO, A.; NOCERA, F.; BRUNO, M.; CARDILLO, G. Development of an equilibrium-based model of gasification of biomass by Aspen Plus. Energy Procedia, v. 111, p. 1010-1019, 2017. Disponível em: <https://doi.org/10.1016/j.egypro.2017.03.264>. doi: 10.1016/j.egypro.2017.03.264.

GARCÍA-IBAÑEZ, P.; CABANILLAS, A.; SÁNCHEZ, J. M. Gasification of leached orujillo (olive oil waste) in a pilot plant circulating fluidised bed reactor. Preliminary results. Biomass \& Bioenergy, v. 27, p. 183-194, 2004, Disponível em: <http://dx.doi.org/10.1016/j.biombioe.2003.11.007>. doi: 10.1016/j.biombioe.2003.11.007.

GERBER, S.; BEHRENDT, F.; OEVERMANN, M. An Eulerian Modeling Approach of Wood Gasification in a Bubbling Fluidized Bed Reactor Using Char as Bed Material. Fuel, v. 89, p. 2903-2917, 2010. Disponível em: <http://dx.doi.org/10.1016/j.fuel.2010.03.034>. doi: 10.1016/j.fuel.2010.03.034.

GIDASPOW, D.; JUNG, J.; SINGH, R. K. Hydrodynamics of fluidization using kinetic theory: an emerging paradigm: 2002 Flour-Daniel lecture. Powder Technology, v. 148, p. 123-141, 2004. Disponível em: <https://doi.org/10.1016/j.powtec.2004.09.025>. doi: 10.1016/j.powtec.2004.09.025.

HOU, B.; WANG, X.; ZHANG, T.; LI, H.; Eulerian simulation of a circulating fluidized bed with a new flow structure-based drag model. Chemical Engineering Journal, v. 284, p. 1224-1232, 2016. Disponível em: <https://doi.org/10.1016/j.cej.2015.09.073>. doi: 10.1016/j.cej.2015.09.073.

ISMAIL, T. M.; EL-SALAM, M. A.; MONTEIRO, E.; ROUBOA, A. Eulerian-Eulerian CFD model on fluidized bed gasifier using coffee husks as fuel. Applied Thermal Engineering, v. 106, p. 1391-1402, 2016. Disponível em: <http://dx.doi.org/10.1016/j.applthermaleng.2016.06.102>. doi: 10.1016/j.applthermaleng.2016.06.102. 
LIU, H.; ELKAMEL, A.; LOHI, A.; BIGLARI, M. Computational fluid dynamics modeling of biomass gasification in circulating fluidized-bed reactor using the eulerian-eulerian approach. Industrial \& Engineering Chemistry Research, v. 52, p. 18162-18174, 2013. Disponível em: <http://dx.doi.org/10.1021/ie4024148>. doi: 10.1021/ie4024148.

LV, X.; LI, H.; ZHU, Q.; LI, J.; Zou, Z. The experiment and simulation of mass transfer in bubbling fluidized beds. Powder Technology, v. 292, p. 323-330, 2016. Disponível em: <https://doi.org/10.1016/j.powtec.2016.02.001/>. doi: 10.1016/j.powtec.2016.02.001/.

PÄRSSINEN, J. H.; ZHU, J.-X. Particle velocity and flow development in a long and high-flux circulating fluidized bed riser. Chemical Engineering Science, v. 56, p. 5295-5303, 2001. Disponível em: <https://doi.org/10.1016/S0009-2509(01)00200-7>. doi: 10.1016/S0009-2509(01)00200-7.

PATEL, K. D.; SHAH, N. K.; PATEL, R. N. CFD Analysis of a spatial distribution of various parameters in downdraft gasifier. Procedia Engineering, v. 51, p. 764-769, 2013. Disponível em: <http://dx.doi.org/10.1016/j.proeng.2013.01.109>. doi: 10.1016/j.proeng.2013.01.109.

SANSANIWAL, S. K.; PAL, K.; ROSEN, M. A.; TYAGI, S. K. Recent advances in the development of biomass gasification technology: A comprehensive review. Renewable and Sustainable Energy Reviews, v. 72, p. 363-384, 2017. Disponível em: <http://dx.doi.org/10.1016/j.rser.2017.01.038>. 10.1016/j.rser.2017.01.038.

SHAH, M. T.; UTIKAR, R. P.; TADE, M. O.; PAREEK, V. K.; EVANS, G. M. Simulation of gas-solid flows in riser using energy minimization multiscale model: Effect of cluster diameter correlation. Chemical Engineering Science, v. 66, p. 3291-3300, 2011. Disponível em: <http://dx.doi.org/10.1016/j.ces.2011.01.056>. doi: 10.1016/j.ces.2011.01.056.

SHARMA, S.; SHETH, P. N. Air-steam biomass gasification: Experiments, modeling and simulation. Energy Conversion and Management, v. 110, p. 307-318, 2016. Disponível em: <http://dx.doi.org/10.1016/j.enconman.2015.12.030>. doi: 10.1016/j.enconman.2015.12.030.

VILLETTA, M. L.; COSTA, M.; MASSAROTTI, N. Modelling approaches to biomass gasification: A review with emphasis on the stoichiometric method. Renewable and Sustainable Energy Reviews, v. 74, p. 71-88, 2017. Disponível em: <https://doi.org/10.1016/j.rser.2017.02.027>. doi: 10.1016/j.rser.2017.02.027.

WANG, J.; LIU, Y. EMMS-based Eulerian simulation on the hydrodynamics of a bubbling fluidized bed with FCC particles. Powder Technology, v. 197, p. 241-246, 2010. Disponível em: <https://doi.org/10.1016/j.powtec.2009.09.022>. doi: 10.1016/j.powtec.2009.09.022.

WANG, X.; JIN, B.; ZHONG, W. Three-dimensional simulation of fluidized bed coal gasification. Chemical Engineering and Processing: Process Intensification, v. 
48, p. 695-705, 2009. Disponível em: <http://dx.doi.org/10.1016/j.cep.2008.08.006>. doi: 10.1016/j.cep.2008.08.006.

WU, Y.; LIU, D.; MA, J.; CHEN, X. Effects of gas-solid drag model on EulerianEulerian CFD simulation of coal combustion in a circulating fluidized bed. Powder Technology, v. 324, p. 48-61, 2018. Disponível em: <https://doi.org/10.1016/j.powtec.2017.10.013>. doi: 10.1016/j.powtec.2017.10.013.

YANG, N.; WANG, W.; GE, W.; WANG, L.; LI, J. Simulation of heterogeneous structure in a circulating fluidized-bed riser by combining the two-fluid model with the EMMS approach. Industrial \& Engineering Chemistry Research, v. 43, p. 55485561 2004. Disponível em: <http://dx.doi.org/10.1021/ie049773c>. doi: 10.1021/ie049773c.

ZHIXIN, Z.; HU, S.; LIU, X.; ZHAO, H. Modeling the hydrodynamics of cocurrent gassolid downers according to energy-minimization multi-scale theory. Particuology, $v$. 29, p. 110-119, 2016. Disponível em: <https://doi.org/10.1016/j.partic.2016.01.011>. doi: 10.1016/j.partic.2016.01.011. 